\title{
The impact of increasing urban surface albedo on outdoor summer thermal comfort within a university campus ${ }^{1}$
}

\author{
Mohammad Taleghani \\ School of the Built Environment, University of Salford, Manchester, UK
}

\begin{abstract}
The impact of increasing urban surface albedo on outdoor thermal comfort was studied in two phases:

Firstly, the thermal conditions of three locations with different ground surface materials were compared. The study used CFD modelling followed by a measurement campaign to validate the control simulation. It was observed that the physiological equivalent temperature (PET as the outdoor thermal comfort index) in the campus park (covered with grass) was $11.0^{\circ} \mathrm{C}$ lower than the parking lot (paved with concrete) at 16:00 CET.

As the next step, the albedo of the roofs and walls were increased from 0.2 to 0.6 . It was found that increasing the albedo made the open space of the courtyard uncomfortable due to the higher reflectivity of high-albedo materials. An increase of every 0.1 albedo of the surfaces led to $1.2^{\circ} \mathrm{C}$ higher mean radiant temperature, and consequently, $0.8^{\circ} \mathrm{C}$ higher PET. The study also showed that the increase of albedo radiated more sun to the ground surface. This increased average ground surface sensible heat flux $\left(6.7 \mathrm{~W} / \mathrm{m}^{2}\right)$ and surface temperature $\left(0.4^{\circ} \mathrm{C}\right)$ during the day. This finding shows that the position and orientation of high albedo materials can significantly affect pedestrians' thermal comfort in urban open spaces.
\end{abstract}

\section{Keywords}

Outdoor thermal comfort, surface albedo, university campus, PET, heat balance

\footnotetext{
${ }^{1}$ Portions of this paper has appeared in PLEA Conference 2017 in Edinburgh, UK. Corresponding author: Mohammad Taleghani, m.taleghani@salford.ac.uk
} 


\section{Introduction}

Outdoor thermal comfort has been studied recently due to the ongoing global warming. Several heat waves caused thousands of heat related mortality all around the world (Andersona and Bell 2009). As a consequence, heat has become the first natural cause of mortality in the US and many countries (Kalkstein et al. 2013). Nowadays, most of the large cities deal with heat waves, even in cold climates like Moscow (Lokoshchenko 2014). During the summer 2003, around 3000 heat related mortality were reported in the Netherlands (Robine et al. 2008). The higher air temperature in cities compared to suburbs is called the urban heat island phenomena (Oke 2002; Rosenfeld et al. 1995). UHI affects energy consumption (Akbari and Matthews 2012; Rodríguez-Álvarez 2016; Santamouris et al. 2001; Ward and Grimmond 2017), air quality (Li and Bou-Zeid 2014; Taha et al. 1997) and peoples' health (Epstein and Moran 2006; Metzger et al. 2010; Taleghani et al. 2016) in cities. This paper is focused on pedestrians' thermal comfort in outdoor environment where there is limited access to a cool spot or a cold drink. Thermal comfort is defined as "that condition of mind which expresses satisfaction with the thermal environment" (ISO-7730 2005). Thermal comfort includes environmental factors (such as air temperature and wind speed), biological factors (such as age and gender), and physiological factors (such as clothing and metabolism) (Ali-Toudert and Mayer 2007; Nicol et al. 2012; Taleghani 2014).

\subsection{Climate change in the Netherlands}

The Netherlands, as a delta country, is affected by climate change. Climate change is contributing to rising sea levels, and this makes coastal cities vulnerable. The oldest weather station in the Netherlands is located in De Bilt. This weather data has been recorded since 1901. According to the historical data, the average air temperature has increased $1.4^{\circ} \mathrm{C}$ between 1951 and 2013. This increase is twice the global average (KNMI 2015b). The Royal Netherlands Meteorological Institute (KNMI), as the Dutch national weather service has produced four climate scenarios based on IPCC fifth report (IPCC 2013) for 2050 and 2085. Based on these scenarios, air temperature increase for December, January and February (winter) is larger than March, April and May (spring). The temperature changes in the scenarios are briefly described in Table 1 . Based on these future scenarios, urban spaces must be designed in a way to mitigate the impact of global warming on citizens' health. A practical way to make urban spaces ready for warmer futures is to adjust the albedo of surfaces. In the following section, the importance of high-albedo materials is explained.

Table 1: Air temperature change in the Netherlands in 2050 and 2085 (Table after (KNMI 2015b)).

\begin{tabular}{|l|c|c|c|c|}
\hline & \multicolumn{2}{|c|}{2050} & \multicolumn{2}{c|}{2085} \\
\hline Emission scenario & Lowest & Highest & Lowest & Highest \\
\hline Mean temperature & +1 & +2 & +1.5 & +3.5 \\
\hline
\end{tabular}

\subsection{Reflective pavements as a heat mitigation strategy}

Heat mitigation strategies are generally referred to changing the land cover in a way to reduce solar absorption. It should be noted that to reduce the energy consumption in cities, several heat mitigation strategies researched and implemented in different climates and in various scales. However, few efforts and studies have addressed the impact of such heat mitigation strategies on outdoor thermal comfort. 
Heat mitigation strategies are used to reduce net radiation from a system. In this paper, the system is a neighbourhood. In this case, net radiation is the balance between incoming and outgoing energy at the neighbourhood scale. Net radiation is calculated by Equation 1:

$R_{n}=H+L E+G$

Where; $R_{n}$ is net radiation, $H$ is sensible heat flux, $L E$ is latent heat flux, and $G$ is soil heat flux (all units are in $\mathrm{W} / \mathrm{m}^{2}$ ).

Erell (2017) divides heat mitigation strategies to cool roofs, cool pavements, and vegetation. This paper focuses on cool pavements, which in practice means to implement light coloured materials on the ground surface (Akbari et al. 2008; Kleerekoper et al. 2017; Taha 2008; Taleghani 2018; Zhang et al. 2017). These materials may reflect a large portion (depending on their albedo) of sun to the sky. In this way, high-albedo materials reduce $\mathrm{H}$ (sensible heat flux) in Eq 1. Consequently, the system (neighbourhood) becomes cooler.

As most of the current urban spaces are covered with asphalt and concrete, solar radiation is absorbed (because of the low albedo) and trapped (because of the high heat capacity) in cities (Dan et al. 2014). In a large scale, white surfaces in Almeria (Spain) have made the air temperature of this city $0.3^{\circ} \mathrm{C}$ cooler than its suburbs (Campra et al. 2008).

In a neighbourhood scale, Santamouris et al. (2012) studied the effect of adapting $4500 \mathrm{~m}^{2}$ of high-albedo pavements on the local microclimate of a park in Athens. In a typical summer day, they observed that the air temperature was $1.9^{\circ} \mathrm{C}$ reduced while the ground surface temperature showed $12{ }^{\circ} \mathrm{C}$ reduction. Similar to this study, Kyriakodis and Santamouris (2017) investigated the cooling effect of another large scale implementation of high-albedo materials in Wester Athens $\left(37,000 \mathrm{~m}^{2}\right)$. They observed that their "cool asphaltic and concrete pavements" could reduce the air temperature and surface temperature by up to 1.5 ${ }^{\circ} \mathrm{C}$ and $11.5^{\circ} \mathrm{C}$, respectively.

There is a body of literature that shows the positive impacts of high-albedo materials on local microclimate and building energy use; however, a few studies have shown changing the albedo of the roofs may not affect near ground surface thermal conditions (Taleghani et al. 2016). Furthermore, Erell et al. (2014) showed that using high-albedo materials could reduce air temperature, but increased the heat stress of pedestrians. Therefore, more studies need to be done on the impact of high-albedo materials at the ground level on pedestrians' comfort.

To address this gap in the current knowledge on high-albedo materials, in this paper, pedestrian thermal comfort within a university campus will be studied through computer simulation. This phase of the study will be followed by a measurement campaign to validate the control simulations. As the next step, the impact of high-albedo materials at the roofs and walls of the university building on pedestrians' comfort will be investigated.

\section{Methodology}

This research investigated the thermal conditions at (a specific part of) the campus of Delft University of Technology in The Netherlands. Computer simulations and field measurements have been carried out. The aim was to investigate the impact of high-albedo surfaces on outdoor thermal comfort of pedestrians. Further simulations were performed to improve the thermal comfort within the open space of one of the university buildings called Science Centre. This building consists of two courtyards. The ground floor of this building is 
dedicated to Delft Technical Museum, and the upper floors are offices. One of the courtyards is used for events. The validation part of this research was performed at this courtyard (Fig 1 , point A). Point B is located at the Botanical Garden of the University, and it is within a park full of grass and trees. Point $C$ is a parking lot covered with concrete pavement.

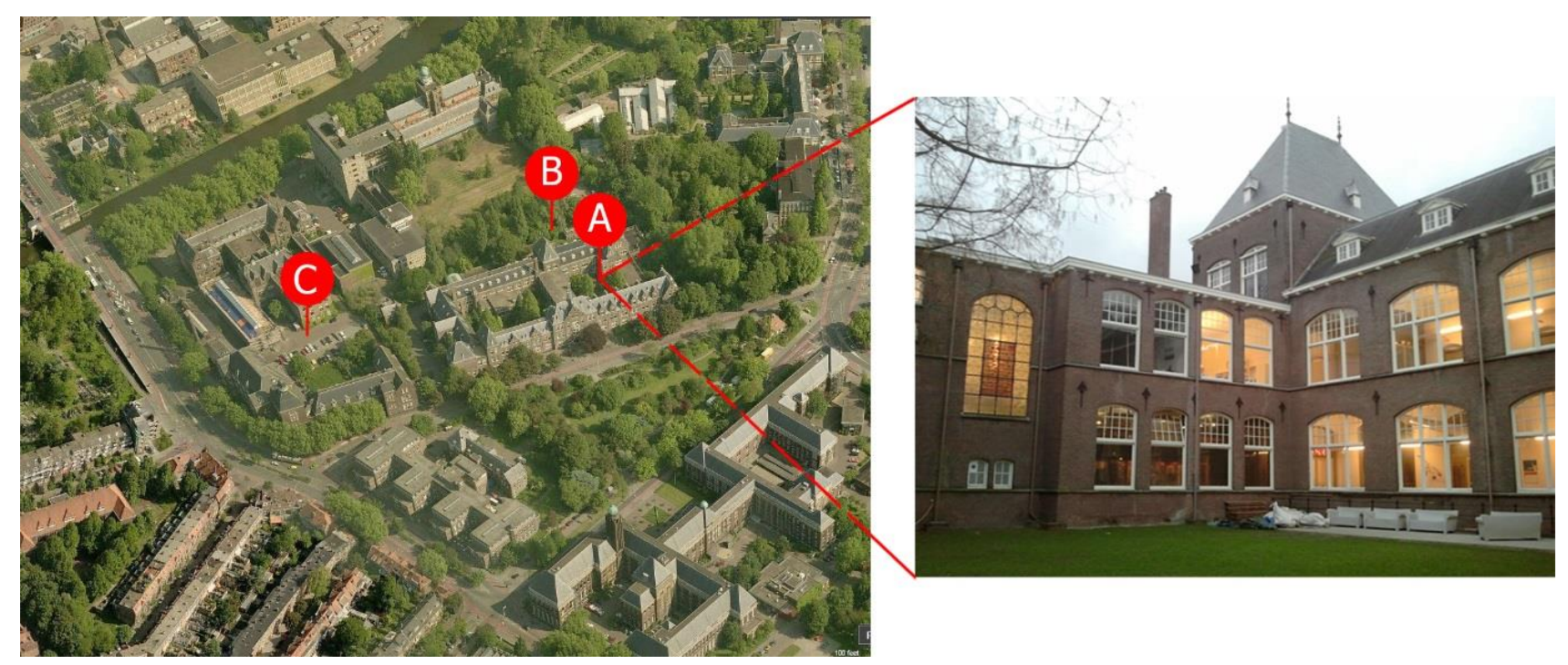

Figure 1: The simulated area as part of the campus of Delft University of Technology (left); the courtyard of Delft Science Centre (right).

The climate of The Netherlands in West Europe is defined as maritime climate (Kottek et al. 2006) with warm summers and cool winters. Based on the average 30 years' weather data (1981-2010) of KNMI (The Royal Netherlands Meteorological Institute), the average high air temperature in July is $22.8^{\circ} \mathrm{C}$ and the average low air temperature in February is $0.2{ }^{\circ} \mathrm{C}$ (KNMI 2015a).

A measurement was performed within the courtyard (point $A$, at the middle of the courtyard at the height of $1.5 \mathrm{~m}$ ). Based on the recorded weather data, CFD simulation by ENVI-met was done and the thermal condition of the campus was studied. Through a biometeorological simulation tool, called RayMan, outdoor thermal comfort conditions were calculated for the points A, B and C. Figure 2 shows a thermal image of the eastern façade of the Science Centre building on the $14^{\text {th }}$ of June 2017. The photo was taken at 15:00 when the air temperature was $25.8^{\circ} \mathrm{C}$. This figure shows how the dark surfaces of the façade absorb solar radiation and their surface temperatures reach to $54^{\circ} \mathrm{C}$. 

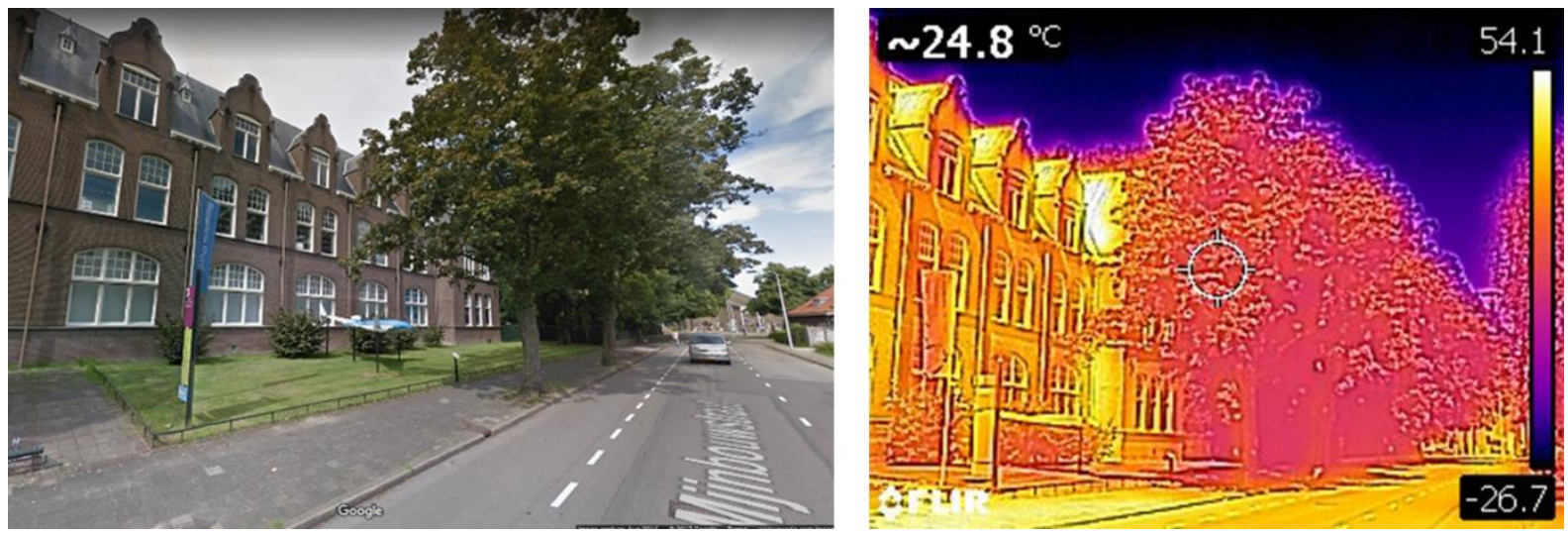

Figure 2: A view of the eastern façade of the Science Centre building (left); and the surface temperature of the façade. The emissivity was set to 0.90 .

ENVI-met v.4.1 Pro (Bruse 2015) is a high resolution computational fluid dynamic (CFD) program with the grid cell size of 0.5 to 10 meters. ENVI-met includes humidity and air temperature (by advection diffusion equations), turbulence and wind flow (by the nonhydrostatic incompressible NavierStokes equations in the Boussinesq-approximated form).

One of the main benefits of using ENVI-met compared to the other CFD models is the fact that the evapotranspiration of vegetation is included in this model. There are two main input files for running a simulation by ENVI-met; the input file (.in) and the configuration file (.cf) (Bruse 2004). The input file is the model that describes the physical properties of the simulation area including buildings, ground surface and plants. The configuration file refers to the initial weather data, the duration, time and data of simulation, and the thermal properties of building walls and roofs (Table 2).

Table 2: Simulation conditions used in ENVI-met.

\begin{tabular}{|l|l|}
\hline Coordination & Latitude $+52.10 ;$ Longitude +4.22 (Delft, The Netherlands) \\
\hline Main model area $\left(\mathrm{x}^{*} \mathrm{y}^{*} \mathrm{z}\right.$ cells) & $153^{*} 107^{*} 30$ \\
\hline Simulation day & 19.09 .2013 \\
\hline Simulation period & $22 \mathrm{~h}(04: 00-02: 00)$ \\
\hline Initial air temperature & $18.8^{\circ} \mathrm{C}$ \\
\hline Initial Wind speed & $2.7 \mathrm{~m} / \mathrm{s}$ \\
\hline Initial Wind direction & $90^{\circ}($ East) \\
\hline Initial Relative humidity (in $2 \mathrm{~m})$ & $70.0 \%$ \\
\hline Indoor temperature & $20.0^{\circ} \mathrm{C}$ \\
\hline Thermal conductance & Walls $1.2 \mathrm{~W} / \mathrm{m}^{2} \mathrm{~K} ;$ Roofs $1.6 \mathrm{~W} / \mathrm{m}^{2} \mathrm{~K}$ \\
\hline Surface albedo & Walls $0.2 ;$ Roofs 0.2 \\
\hline Spatial resolution & $1 \mathrm{~m}$ horizontally, $2 \mathrm{~m}$ vertically \\
\hline Cloud coverage & 0 Octa (clear sky) \\
\hline
\end{tabular}

RayMan (Matzarakis et al. 1999; Matzarakis et al. 2007) is a bio-meteorological program, which computes the environmental and personal factors and generates a thermal comfort index called Physiological Equivalent Temperature (PET). PET is in degree Celsius. It is based on the thermo-physiological heat balance model of human body called MEMI (Munich energy balance model for individuals) (Höppe 1999; Matzarakis and Endler 2010). For further readings about the validation of RayMan please see Lee and Mayer (2016). 
For the calculation of PET in this paper, the input data were air temperature, wind speed, relative humidity, mean radiant temperature (as environmental factors), and clothing, activities, gender and age (as personal factors). The environmental factors data for the simulation of thermal comfort were derived from ENVI-met. The personal factors were based on a typical young male walking in the campus (Table 3).

Table 3: Simulation conditions used in RayMan for the calculation of outdoor thermal comfort.

\begin{tabular}{|l|l|}
\hline Clothing & $\begin{array}{l}0.57 \mathrm{Clo}=\text { Socks }(0.02 \mathrm{Clo})+\text { Straight trousers }(0.24 \text { Clo })+\text { Shoes } \\
(0.02 \mathrm{Clo})+\text { Men's brief }(0.04 \mathrm{Clo})+\text { Long Sleeve dress shirt }(0.25 \mathrm{Clo})\end{array}$ \\
\hline Activity & $80 \mathrm{~W}($ equal to walking $)$ \\
\hline Personal data & $1.75 \mathrm{~m}, 75 \mathrm{~kg}, 35$ years, male \\
\hline
\end{tabular}

\section{Measurement campaign at the centre of the courtyard}

To validate the simulation results, the air temperature data from ENVI-met was compared with the actual measured data within the courtyard of the science centre. The measured data was recorded by a Vantage Pro2 weather station with an interval of 5 minutes, on the $19^{\text {th }}$ of September 2013. The operating range of the data logger is between -40 to $+74^{\circ} \mathrm{C}$ with the accuracy of $\pm 0.5^{\circ} \mathrm{C}$. To have a better understanding of the differences between the measured and simulated air temperature, root mean square deviation (RMSD) was calculated. To calculate the RMSD, Equation 2 was used:

$R M S D=\sqrt{\frac{\sum_{1}^{n}(T s-T m)^{2}}{n}}$

Where $T_{s}$ is simulated air temperature, and $T_{m}$ is measured air temperature.

Calculated RMSD showed that the ENVI-met results for the centre of the courtyard have 1.8 ${ }^{\circ} \mathrm{C}$ deviation from the recorded weather data during the day on average. The most deviated results were between 9:00 CET and 15:00 CET. Figure 3 top shows the measured versus simulated air temperature. Figure 3 bottom shows the calculated $\mathrm{R}^{2}$, which expresses how close the data are to the regression line. This index ranges between 0 and 1 , and it is 0.9073 in the comparison of measured versus simulated air temperature. 

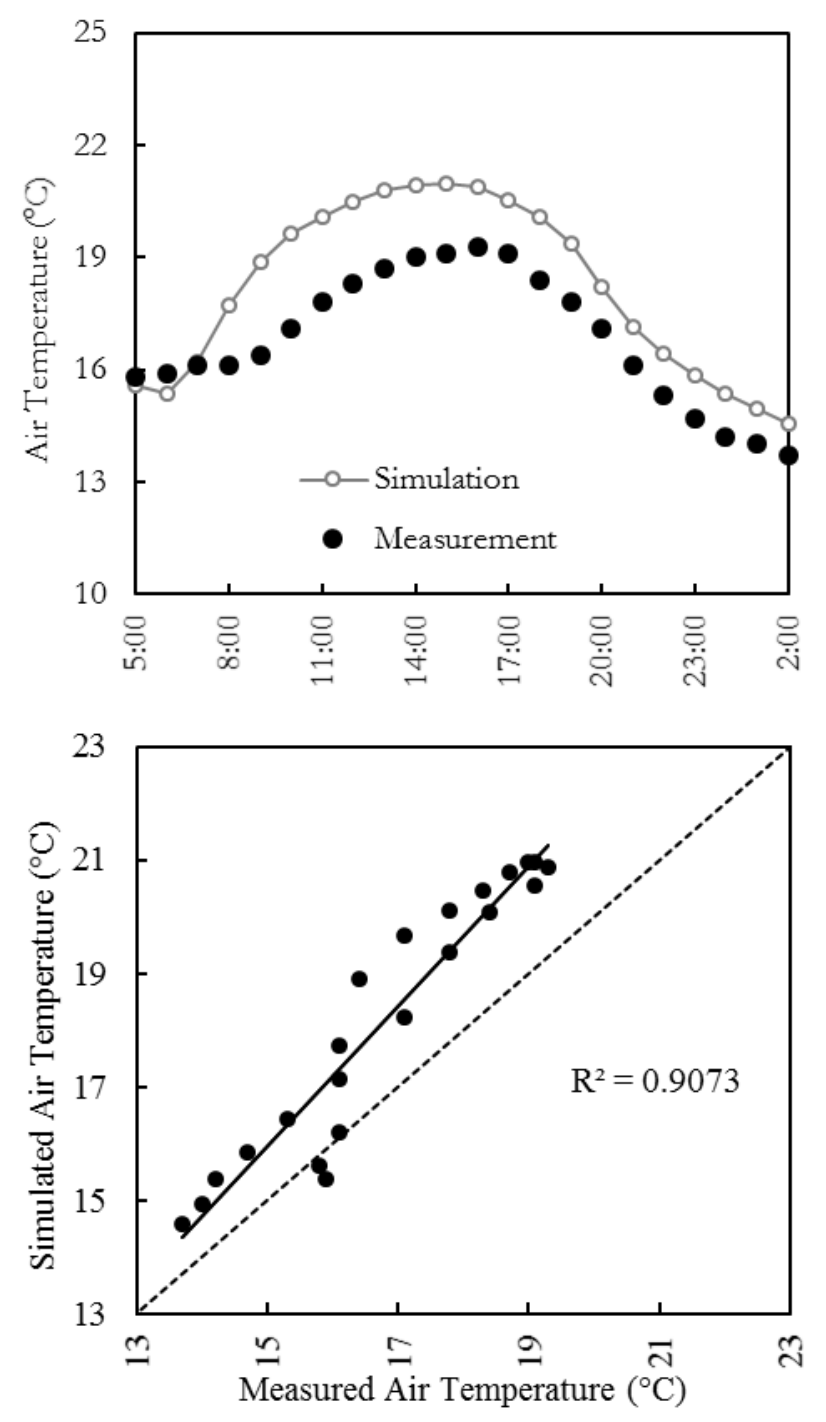

Figure 3: Top, the comparison of measured versus simulated air temperatures within the courtyard. Bottom, the scatter plot showing the $\mathrm{R}^{2}$ for the measured versus simulated air temperature at the height of $1.5 \mathrm{~m}$.

\section{Results}

\subsection{The actual thermal condition}

Figure 4-a shows the air temperature at the height of $1.5 \mathrm{~m}$ within the simulated area at 16:00 CET. The air temperature ranges between 21.2 to $23.7^{\circ} \mathrm{C}$. There is a concentration of higher air temperature at the east side of the area. This area is an intersection and there is more asphalt pavement compared to the rest of the area. During the day, the asphalt surface with a low albedo reflects less sun compared to the rest of the pavements. Moreover, asphalt has a high heat capacity and releases the heat in late afternoon and evening. This makes the intersection as the hottest spot in the area at 16:00.

Several studies have shown the effect of mean radiant temperature on the pedestrians' thermal comfort (Herrmann and Matzarakis 2012; Kántor and Unger 2011; Taleghani and Berardi 2017; Thorsson et al. 2014). Figure 4-b shows the mean radiant temperature ( $\left.T_{\mathrm{mrt}}\right)$ at 
the height of $1.5 \mathrm{~m}$ at 16:00. The figure shows that maximum $T_{\mathrm{mrt}}$ is at the intersection, and this is because of the presence of the asphalt surfaces. Furthermore, high $T_{\mathrm{mrt}}$ is observed above the two parking lots which are white in the figure. Lower mean radiant temperature was estimated under the trees. This is because of the shading of the trees (at the pedestrian height). This might be one of the main reasons that people feel more comfortable in parks. Comparing the hottest and coldest spots in the area, $\mathrm{T}_{\mathrm{mrt}}$ was $51.2^{\circ} \mathrm{C}$ lower in the park than the parking lots.

a)

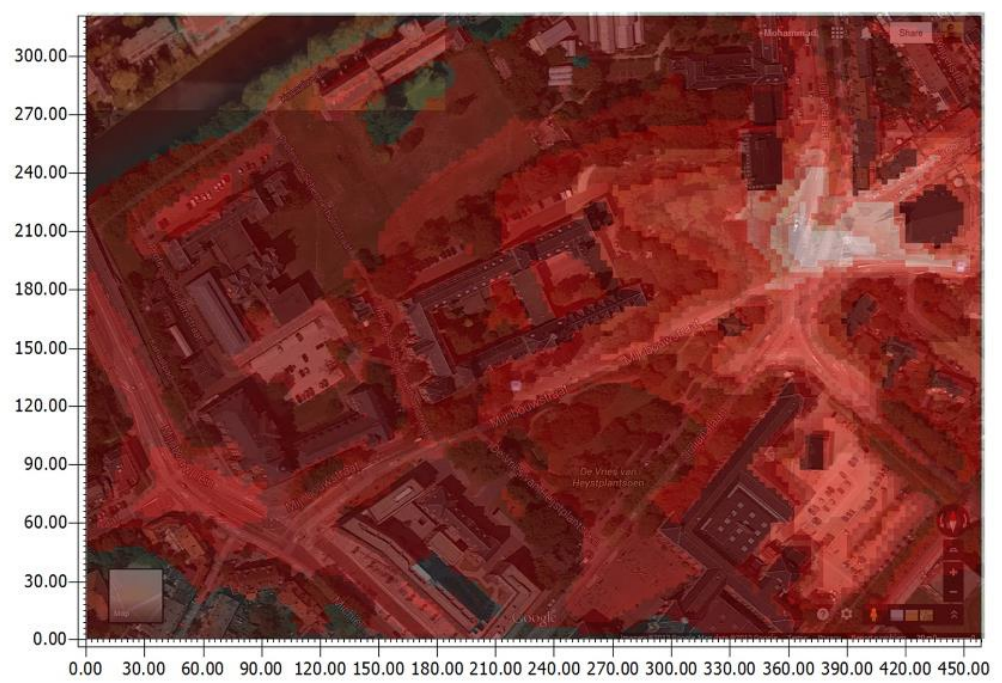

Air Temperature
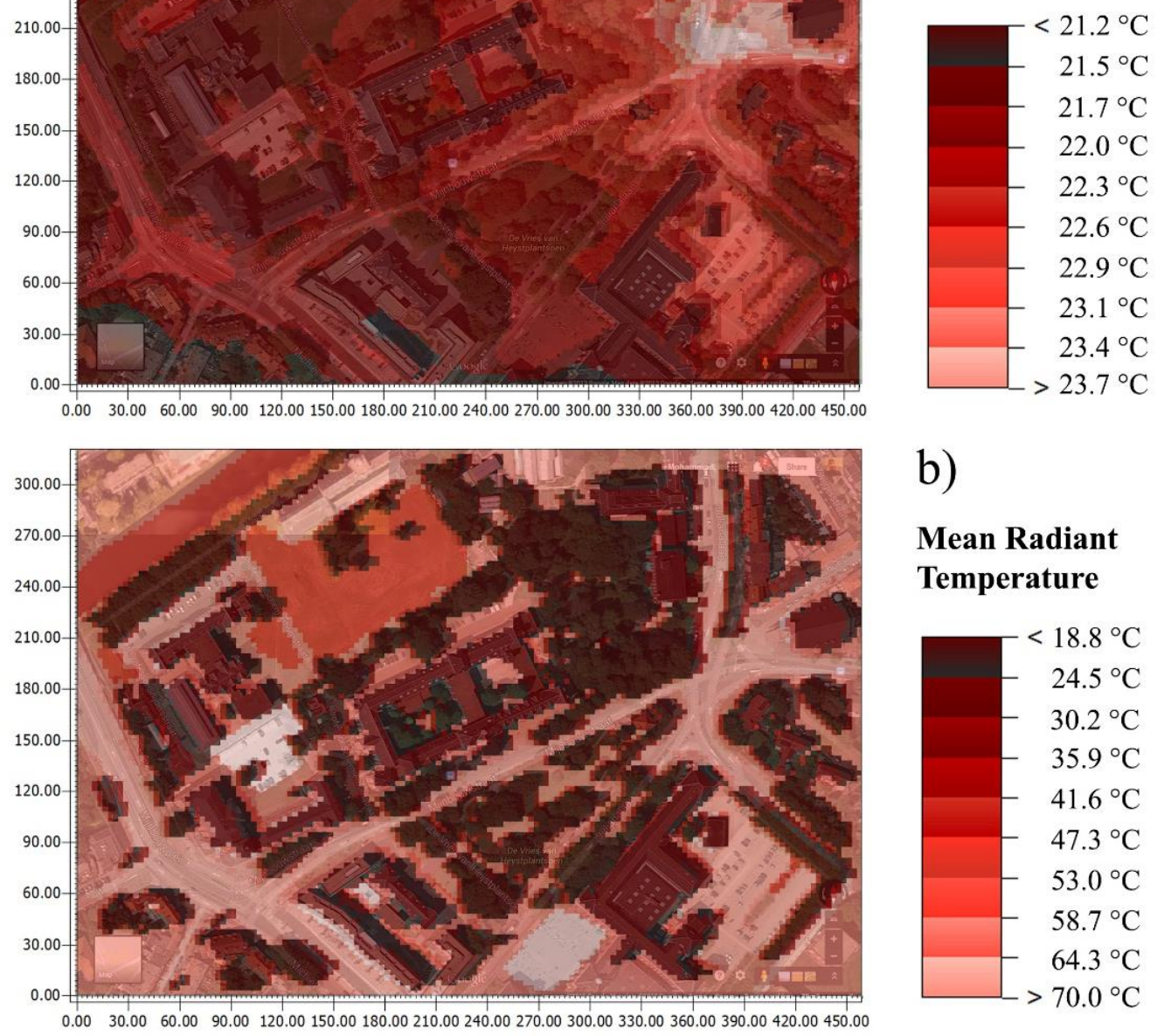

b)

\section{Mean Radiant Temperature}

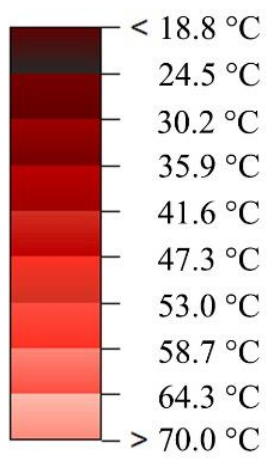

Figure 4: a) Air temperature, and b) mean radiant temperature of the campus at 16:00 on the $19^{\text {th }}$ of September 2013 (at the height of $1.5 \mathrm{~m}$ ).

PET as the thermal comfort index is calculated for three locations. Based on this index, the range of 18 to $23^{\circ} \mathrm{C}$ PET is comfortable, 13 to $18^{\circ} \mathrm{C}$ PET is slightly cool, 23 to $28^{\circ} \mathrm{C} \mathrm{PET}$ is slightly warm, and below 13 and above $28^{\circ} \mathrm{C}$ PET is uncomfortable (Matzarakis et al. 1999). Figure 5 illustrates how PET fluctuates during the day (from 5:00 am till the next day 2:00 am). The parking lot and the north park demonstrated the highest $\left(27.7^{\circ} \mathrm{C}\right)$ and lowest $(22.7$ $\left.{ }^{\circ} \mathrm{C}\right)$ average PET, respectively. The maximum PET was experienced at 16:00 when the heat is releasing from the urban surfaces with high heat capacity materials like asphalt and 
concrete pavements. The maximum PET at the parking lot, courtyard and the north park were $44.6,41.4$ and $33.6{ }^{\circ} \mathrm{C}$, respectively. The thermal condition of the courtyard which has the ground surface covered with grass but surrounded by brick walls is between the park and the parking lot.

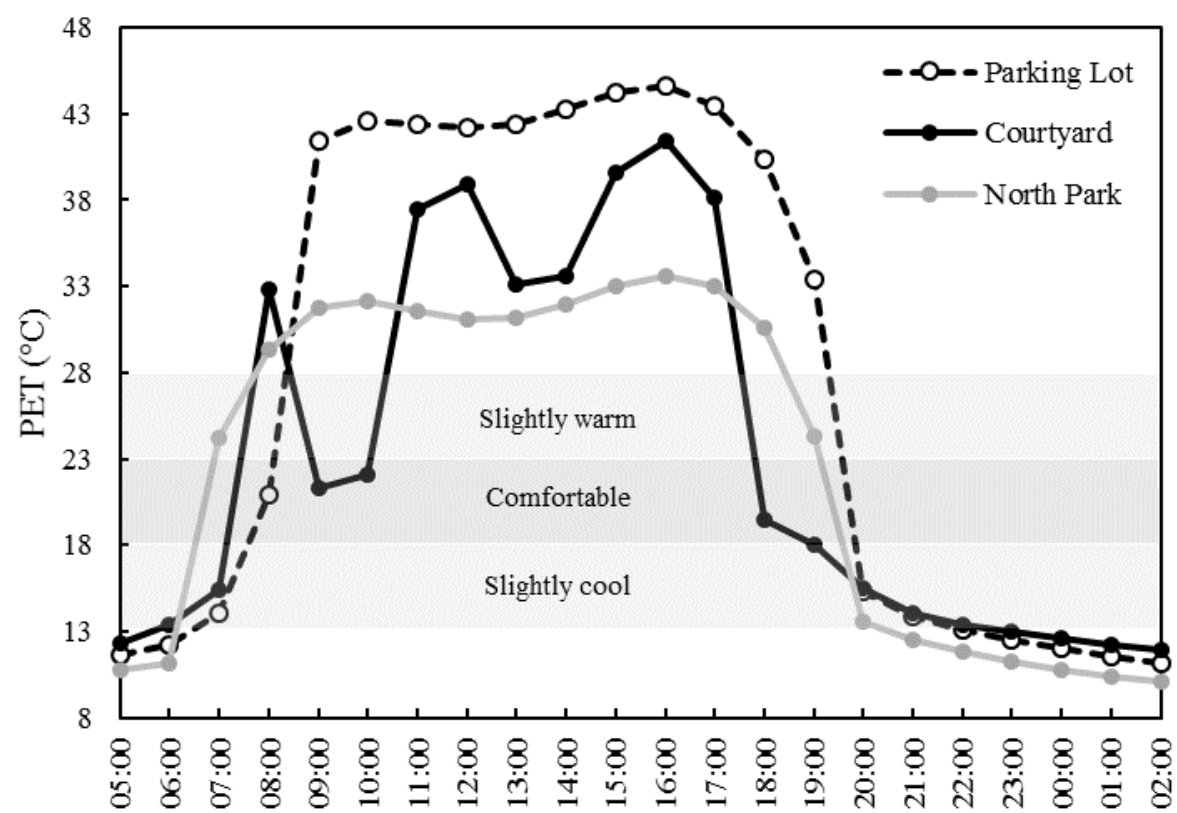

Figure 5: PET in three different locations within the campus on the $19^{\text {th }}$ of September 2013 (at the height of $1.5 \mathrm{~m})$.

\subsection{The impact of higher albedo}

In this phase of the study, the albedo of the walls and roofs are increased from 0.2 (control model) to $0.3,0.4,0.5$ and 0.6 . The increase of albedo was with the aim of improving the thermal condition in the outdoor environment for the pedestrians. Figure 6-a shows the absolute difference of mean radiant temperature between albedo 0.2 and 0.6 . The figure illustrates that $T_{\text {mrt }}$ is amplified around the buildings where the albedo has been increased. In the rest of the simulated area, $\mathrm{T}_{\mathrm{mrt}}$ was not changed.

Figure 6-b illustrates the impact on PET of increasing the albedo from 0.2 to 0.6 . In this figure, the increase of PET within the closed shape of the courtyard is shown. In contrast, the other areas of the campus that are less surrounded by reflective walls, show less PET increase. 


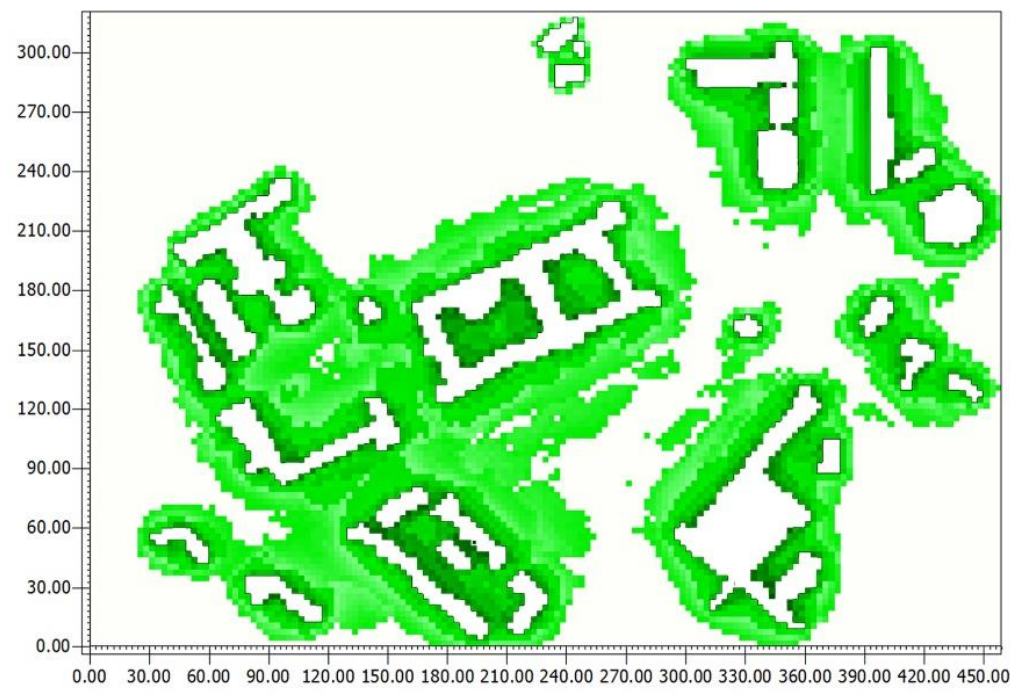

a)

\section{Mean Radiant \\ Temperature \\ Difference}
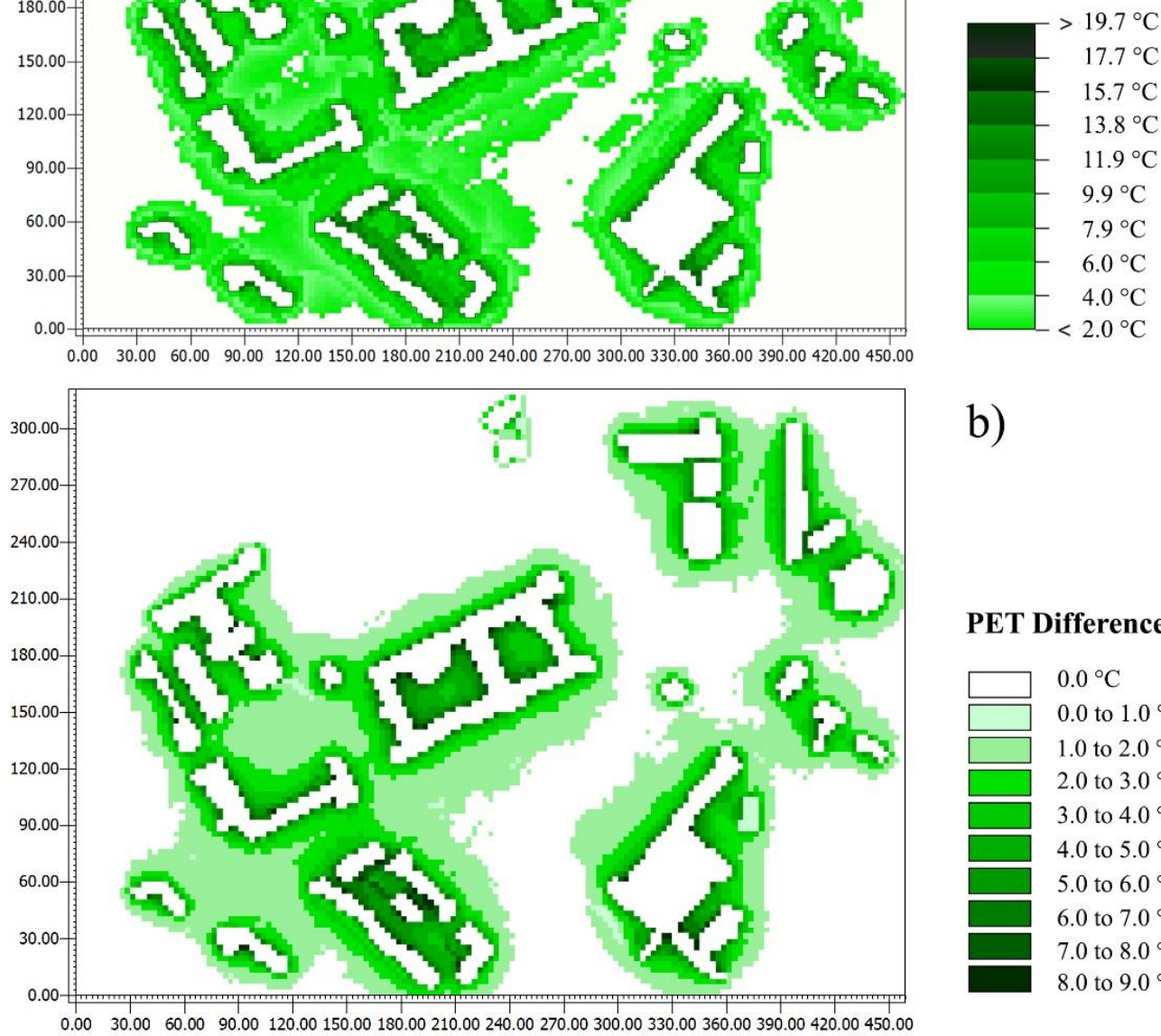

b)

PET Difference

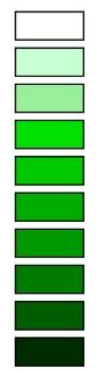

$0.0^{\circ} \mathrm{C}$

0.0 to $1.0^{\circ} \mathrm{C}$

1.0 to $2.0^{\circ} \mathrm{C}$

2.0 to $3.0^{\circ} \mathrm{C}$

3.0 to $4.0^{\circ} \mathrm{C}$

4.0 to $5.0^{\circ} \mathrm{C}$

5.0 to $6.0^{\circ} \mathrm{C}$

6.0 to $7.0^{\circ} \mathrm{C}$

7.0 to $8.0^{\circ} \mathrm{C}$

8.0 to $9.0^{\circ} \mathrm{C}$

Figure 6: a) Mean radiant temperature difference, and b) PET difference when the albedos of the roofs and walls are increased from 0.2 to 0.6 (at 16:00).

Considering the thermal condition of the Science Centre courtyard, Figure 7 shows the PET during the day. It compares PET when the albedo of the walls is 0.2 and 0.6 (at the centre of the courtyard at the height of $1.5 \mathrm{~m}$ ). The comparison shows that increasing the albedo led to the higher PET inside the courtyard during the day. The average difference of PET during the daylight hours (from 6:00 to 19:00) was $3.4^{\circ} \mathrm{C}$, and during the whole day was $2.2^{\circ} \mathrm{C}$. This shows that because of the closed shape of the courtyard, the reflection of sun (due to the higher albedo) led to higher discomfort. 


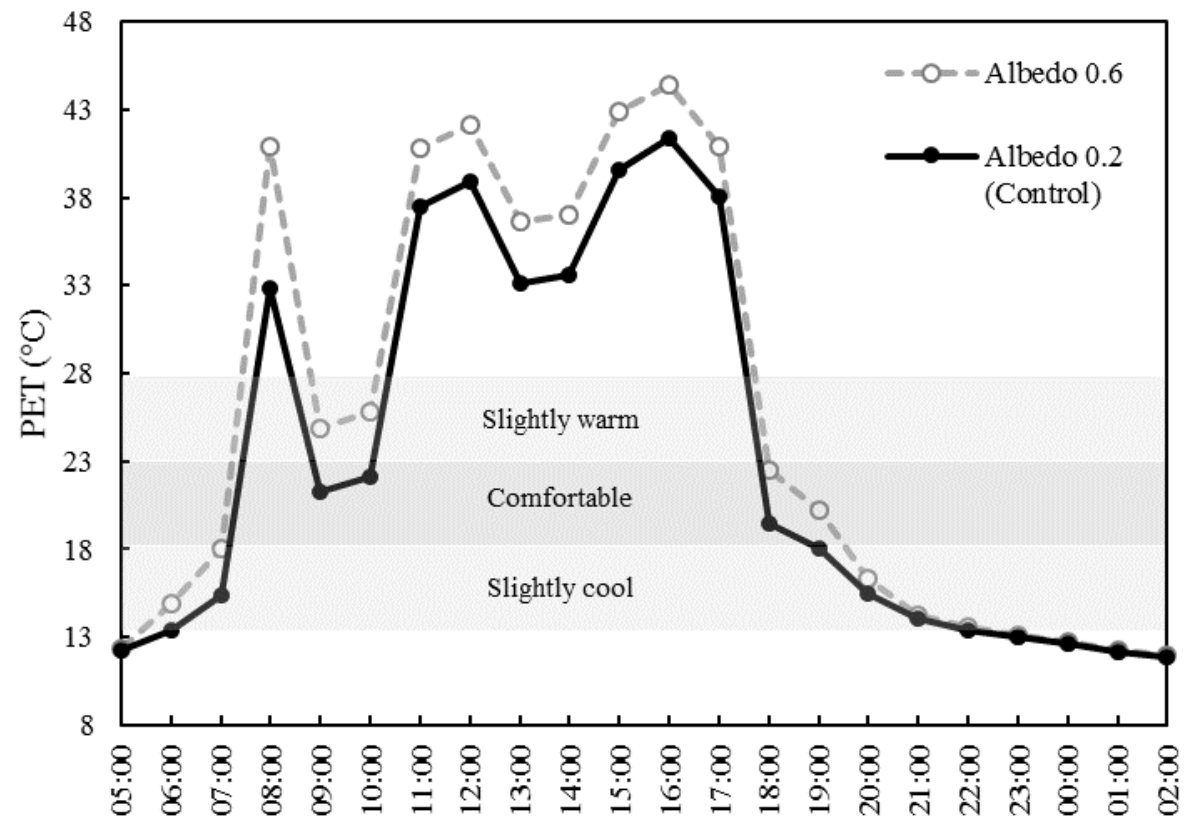

Figure 7: PET at the centre of the courtyard while the albedo of the walls and roofs are 0.2 (control) and 0.6.

To explore the impact of albedo increase on an open area (compared to the closed area of the courtyard), another receptor outside of the courtyard was considered. Figure 8 shows the impact of different albedos on the mean radiant temperature (left) and PET (right) at the inside and outside of the courtyard. The results are based on the thermal condition at 16:00. $\mathrm{T}_{\mathrm{mrt}}$ and PET are increased by the increase of albedo. The increase rate of $\mathrm{T}_{\mathrm{mrt}}$ and PET inside the courtyard is higher than the outside. This is due to the impact of closed environment of the courtyard which amplifies the re-radiation. By increase of each 0.1 albedo, $\mathrm{T}_{\text {mrt }}$ was increased $1.2^{\circ} \mathrm{C}$ inside the courtyard, and $0.9^{\circ} \mathrm{C}$ outside of the courtyard. Likewise, this increase for PET was 0.8 and $0.6^{\circ} \mathrm{C}$ (respectively for inside and outside) which also means a higher rate of increase for the inside of the courtyard compared to the outside.
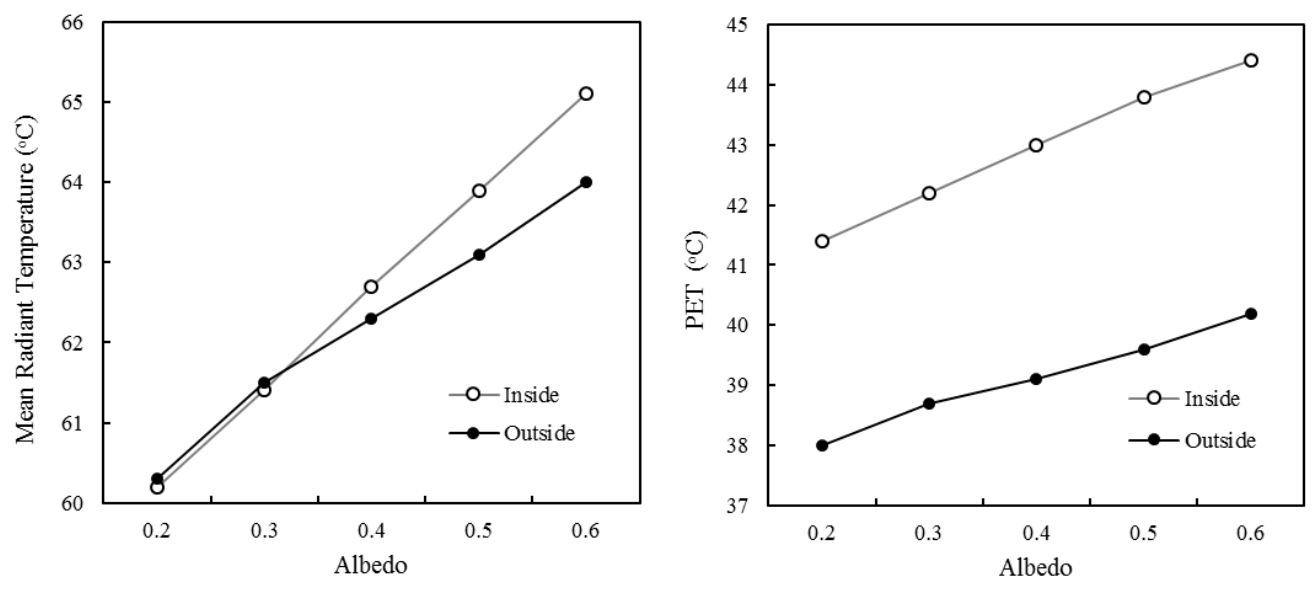

Figure 8: The effect of increasing the albedo of walls and roofs from 0.2 (control) to 0.6 on mean radiant temperature and PET at the centre of the courtyard at 16:00. 
In Figure 9, the diurnal profile of ground surface sensible heat flux (top), and ground surface temperature (bottom), are illustrated. These two diagrams show the hourly data taken from the cells in the neighbourhood domain. Sensible heat is the amount of energy released to the atmosphere. Figures show that by increasing the albedo of the walls, sensible heat flux and ground surface temperatures are increased.

By increasing the albedo from 0.2 to 0.6 , sensible heat flux shows the maximum increase of $12.9 \mathrm{~W} / \mathrm{m}^{2}$ at $13: 00$. The average increase of sensible heat flux during the day is $6.7 \mathrm{~W} / \mathrm{m}^{2}$. Likewise, the ground surface temperature is increased with the average of $0.4{ }^{\circ} \mathrm{C}$ during the day. This shows that the higher albedo has increased the amount of radiation to the ground surface. Consequently, sensible heat flux and surface temperatures are increased, as well.
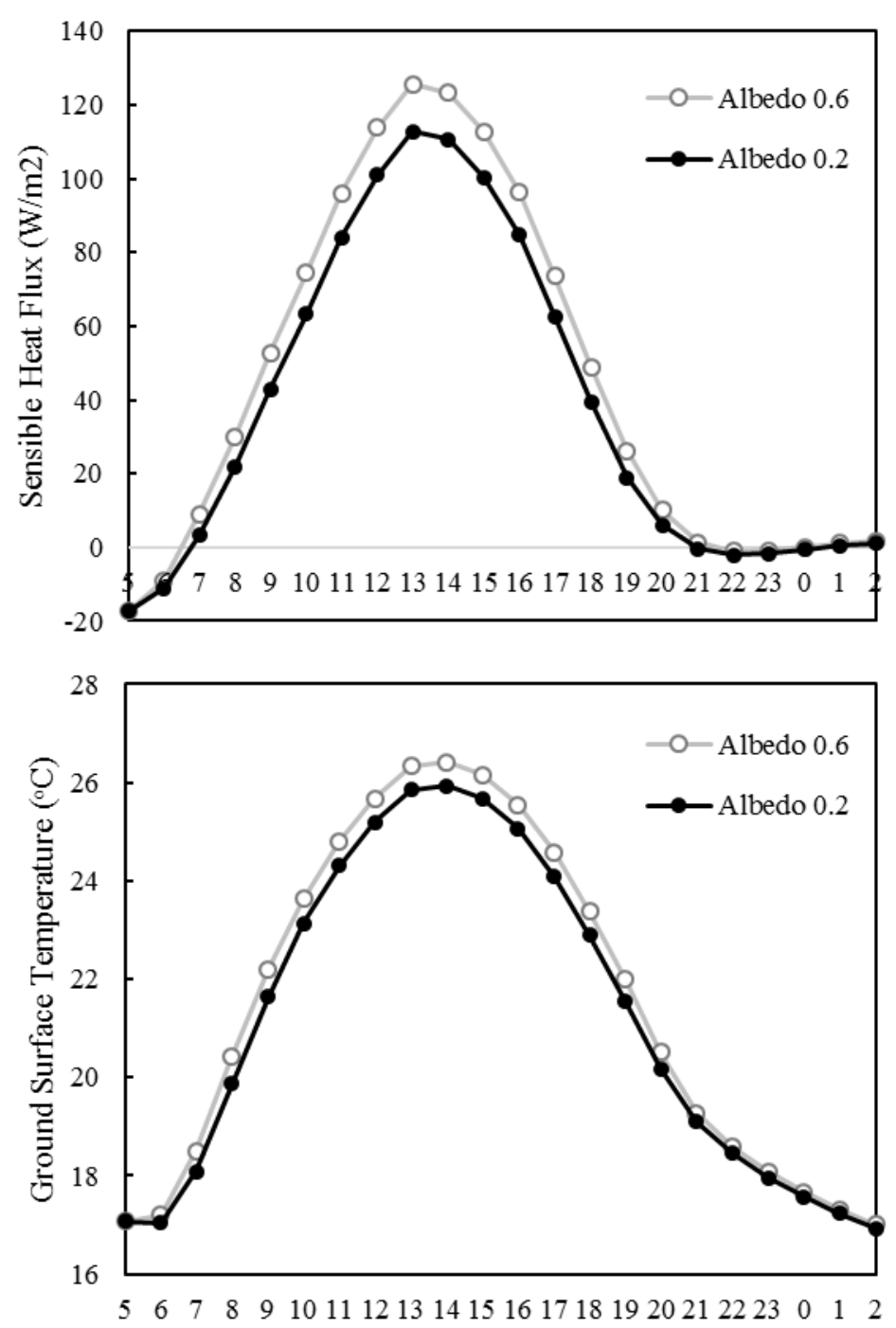

Figure 9: Top: Hourly profile of sensible heat flux; Bottom: hourly profile of ground surface temperature within the whole neighbourhood domain. 


\section{Conclusions}

This paper reviewed the impact of high-albedo materials on outdoor thermal comfort within a courtyard building at the campus of Delft University of Technology. The study was divided into two phases:

In phase one, the thermal condition of the area around the courtyard building was explored through measurement and simulation. This phase of the study showed that PET (as the thermal comfort index used in this paper) at the park of the campus was $11.0^{\circ} \mathrm{C}$ lower than a parking lot covered with concrete pavement.

In phase two, thermal comfort within the courtyard was investigated. The albedo of the roof and walls was increased from 0.2 (control) to $0.3,0.4,0.5$ and 0.6. PET was calculated for each scenario at the centre of the courtyard. The results showed that increasing the albedo of the courtyard walls and roof led to higher mean radiant temperatures within the courtyard. Consequently, higher PET was detected. In fact, by increasing the albedo by 0.1 , PET increased $0.8^{\circ} \mathrm{C}$. In other words, increasing the surface albedo made the open space of the courtyard uncomfortable. As a result, increasing the albedo in a closed microclimate like a courtyard amplifies the re-radiation to human body and decreases thermal comfort.

To better understand the impact of surface albedo on thermal comfort, heat balance was also studied. It was found that the increase of albedo radiated more sun to the ground surface. This increased average sensible heat flux $\left(6.7 \mathrm{~W} / \mathrm{m}^{2}\right)$ and surface temperature $(0.4$ ${ }^{\circ} \mathrm{C}$ ) during the day.

Here it should be noted that most of the literatures in the field of heat mitigation strategies confirm the cooling impact of high-albedo pavements; however, very few of them consider pedestrian's thermal comfort. Thermal comfort mostly depends on mean radiant temperature, and high-albedo materials increase the re-radiation from the ground to the sky. This paper showed that although pedestrians benefit from the air temperature reduction by cool pavements, they will suffer from the increased radiation.

The findings state that the position of high albedo surfaces should be chosen carefully in a way to not re-radiate the sun into pedestrians. For further research in this field, it is recommended to investigate the impact of highly reflective roofs on thermal comfort of people in pedestrian level and indoor environments.

\section{Acknowledgement}

The author would like to acknowledge Farzaneh Fakhredin for taking the thermal photos of this research. 


\section{References}

Akbari H, Matthews HD (2012) Global cooling updates: Reflective roofs and pavements Energy and Buildings 55:2-6 doi:http://dx.doi.org/10.1016/j.enbuild.2012.02.055

Akbari $\mathrm{H}$ et al. (2008) Reducing Urban Heat Islands: Compendium of Strategies. United States Environmental Protection Agency,

Ali-Toudert F, Mayer H (2007) Effects of asymmetry, galleries, overhanging façades and vegetation on thermal comfort in urban street canyons Solar Energy 81:742-754 doi:http://dx.doi.org/10.1016/i.solener.2006.10.007

Andersona BG, Bell ML (2009) Weather-Related Mortality, How Heat, Cold, and Heat Waves Affect Mortality in the United States Epidemiology 20:205-213

Bruse M (2004) ENVI-met 3.0: Updated Model Overview.

Bruse M (2015) ENVI-met website. http://www.envimet.com.

Campra P, Garcia M, Canton Y, Palacios-Orueta A (2008) Surface temperature cooling trends and negative radiative forcing due to land use change toward greenhouse farming in southeastern Spain Journal of Geophysical Research: Atmospheres 113:n/a-n/a doi:10.1029/2008JD009912

Dan L, Bou-Zeid E, Oppenheimer M (2014) The effectiveness of cool and green roofs as urban heat island mitigation strategies Environmental Research Letters 9:055002

Epstein Y, Moran DS (2006) Thermal comfort and the heat stress indices Industrial Health 44:388398

Erell E (2017) Is urban heat island mitigation necessarily a worthy objective? Paper presented at the PLEA 2017- Design to Thrive, Edinburg, UK,

Erell E, Pearlmutter D, Boneh D, Kutiel PB (2014) Effect of high-albedo materials on pedestrian heat stress in urban street canyons Urban Climate 10:367-386 doi:https://doi.org/10.1016/j.uclim.2013.10.005

Herrmann J, Matzarakis A (2012) Mean radiant temperature in idealised urban canyons-examples from Freiburg, Germany Int J Biometeorol 56:199-203 doi:10.1007/s00484-010-0394-1

Höppe $P$ (1999) The physiological equivalent temperature - A universal index for the biometeorological assessment of the thermal environment Int J Biometeorol 43:71-75

IPCC (2013) Intergovernmental Panel on Climate Change 2013 - The Physical Science Basis: Contribution of Working Group I to the Fifth Assessment Report of the IPCC. Stockholm Sweden

ISO-7730 (2005) ISO 7730 2005-11-15 Ergonomics of the Thermal Environment: Analytical Determination and Interpretation of Thermal Comfort Using Calculation of the PMV and PPD Indices and Local Thermal Comfort Criteria. ISO,

Kalkstein LS, Sailor DJ, Shickman K, Sheridan S, Vanos J (2013) Assessing the Health Impacts of Urban Heat Island Reduction Strategies in the District of Columbia. Paper presented at the Global Cool Cities Alliance, Washington, D.C.,

Kántor N, Unger J (2011) The most problematic variable in the course of human-biometeorological comfort assessment - the mean radiant temperature centeurjgeo 3:90-100 doi:10.2478/s13533-011-0010-x

Kleerekoper L, Taleghani M, van den Dobbelsteen A, Hordijk T (2017) Urban measures for hot weather conditions in a temperate climate condition: A review study Renewable and Sustainable Energy Reviews 75:515-533 doi:https://doi.org/10.1016/j.rser.2016.11.019

KNMI (2015a) KNMI'14 climate scenarios for the Netherlands; A guide for professionals in climate adaptation. KNMI, De Bilt, The Netherlands, $34 \mathrm{pp}$

KNMI (2015b) KNMI'14 climate scenarios for the Netherlands; A guide for professionals in climate adaptation. KNMI, De Bilt, The Netherlands, $34 \mathrm{pp}$

Kottek M, Grieser J, Beck C, Rudolf B, Rubel F (2006) World Map of the Köppen-Geiger climate classification updated Meteorologische Zeitschrift 15 doi:10.1127/0941-2948/2006/0130 
Kyriakodis GE, Santamouris M (2017) Using reflective pavements to mitigate urban heat island in warm climates - Results from a large scale urban mitigation project Urban Climate doi:https://doi.org/10.1016/j.uclim.2017.02.002

Lee $\mathrm{H}$, Mayer $\mathrm{H}$ (2016) Validation of the mean radiant temperature simulated by the RayMan software in urban environments Int J Biometeorol 60:1775-1785 doi:10.1007/s00484-0161166-3

Li D, Bou-Zeid E (2014) Quality and sensitivity of high-resolution numerical simulation of urban heat islands Environmental Research Letters 9:055001

Lokoshchenko MA (2014) Urban 'heat island' in Moscow Urban Climate 10, Part 3:550-562 doi:http://dx.doi.org/10.1016/j.uclim.2014.01.008

Matzarakis A, Endler C (2010) Climate change and thermal bioclimate in cities: impacts and options for adaptation in Freiburg, Germany Int J Biometeorol 54:479-483 doi:10.1007/s00484-0090296-2

Matzarakis A, Mayer H, Iziomon MG (1999) Applications of a universal thermal index: physiological equivalent temperature Int J Biometeorol 43:76-84 doi:10.1007/s004840050119

Matzarakis A, Rutz F, Mayer H (2007) Modelling radiation fluxes in simple and complex environments-application of the RayMan model Int J Biometeorol 51:323-334 doi:10.1007/s00484-006-0061-8

Metzger KB, Ito K, Matte TD (2010) Summer heat and mortality in New York City: how hot is too hot? Environmental health perspectives 118:80-86 doi:10.1289/ehp.0900906

Nicol F, Humphreys M, Roaf S (2012) Adaptive Thermal Comfort: Principles and Practice. Taylor \& Francis,

Oke TR (2002) Boundary Layer Climates. Taylor \& Francis,

Robine J-M, Cheung SLK, Le Roy S, Van Oyen H, Griffiths C, Michel J-P, Herrmann FR (2008) Death toll exceeded 70,000 in Europe during the summer of 2003 Comptes Rendus Biologies 331:171178 doi:http://dx.doi.org/10.1016/i.crvi.2007.12.001

Rodríguez-Álvarez J (2016) Urban Energy Index for Buildings (UEIB): A new method to evaluate the effect of urban form on buildings' energy demand Landscape and Urban Planning 148:170187 doi:https://doi.org/10.1016/j.landurbplan.2016.01.001

Rosenfeld AH, Akbari H, Bretz S, Fishman BL, Kurn DM, Sailor D, Taha H (1995) Mitigation of urban heat islands: materials, utility programs, updates Energy and Buildings 22:255-265 doi:http://dx.doi.org/10.1016/0378-7788(95)00927-P

Santamouris M, Gaitani N, Spanou A, Saliari M, Giannopoulou K, Vasilakopoulou K, Kardomateas T (2012) Using cool paving materials to improve microclimate of urban areas - Design realization and results of the flisvos project Building and Environment 53:128-136 doi:http://dx.doi.org/10.1016/i.buildenv.2012.01.022

Santamouris M, Papanikolaou N, Livada I, Koronakis I, Georgakis C, Argiriou A, Assimakopoulos DN (2001) On the impact of urban climate on the energy consumption of buildings Solar Energy 70:201-216 doi:http://dx.doi.org/10.1016/S0038-092X(00)00095-5

Taha H (2008) Urban Surface Modification as a Potential Ozone Air-quality Improvement Strategy in California: A Mesoscale Modelling Study Boundary-Layer Meteorol 127:219-239 doi:10.1007/s10546-007-9259-5

Taha H, Douglas S, Haney J (1997) Mesoscale meteorological and air quality impacts of increased urban albedo and vegetation Energy and Buildings 25:169-177 doi:http://dx.doi.org/10.1016/S0378-7788(96)01006-7

Taleghani M (2014) Dwelling on Courtyards: Exploring the energy efficiency and comfort potential of courtyards for dwellings in the Netherlands. Delft University of Technology

Taleghani M (2018) Outdoor thermal comfort by different heat mitigation strategies- A review Renewable and Sustainable Energy Reviews 81:2011-2018 doi:https://doi.org/10.1016/i.rser.2017.06.010 
Taleghani M, Berardi U (2017) The effect of pavement characteristics on pedestrians' thermal comfort in Toronto Urban Climate doi:https://doi.org/10.1016/j.uclim.2017.05.007

Taleghani M, Sailor D, Ban-Weiss GA (2016) Micrometeorological simulations to predict the impacts of heat mitigation strategies on pedestrian thermal comfort in a Los Angeles neighborhood Environmental Research Letters 11:024003

Thorsson S, Rocklöv J, Konarska J, Lindberg F, Holmer B, Dousset B, Rayner D (2014) Mean radiant temperature - A predictor of heat related mortality Urban Climate 10, Part 2:332-345 doi:http://dx.doi.org/10.1016/j.uclim.2014.01.004

Ward HC, Grimmond CSB (2017) Assessing the impact of changes in surface cover, human behaviour and climate on energy partitioning across Greater London Landscape and Urban Planning 165:142-161 doi:http://dx.doi.org/10.1016/j.landurbplan.2017.04.001

Zhang Y, Du X, Shi Y (2017) Effects of street canyon design on pedestrian thermal comfort in the hothumid area of China Int J Biometeorol doi:10.1007/s00484-017-1320-6 